\title{
Acquired oculomotor muscle fibrosis in infant: case report
}

\author{
Fibrose adquirida de músculo oculomotor em criança: relato de caso
}

\author{
Carlos Ramos de Souza-Dias ${ }^{1}$, Mauro Goldchmit ${ }^{2}$, Carlos Fumiaki UesuguI ${ }^{2}$
}

\begin{abstract}
The authors report the case of a 5 year-old boy who up to 2 years old presented normal eyes, when his right eye started to deviate upward and laterally, until be hidden under the superior lid. At the surgery, astrong passive limitation to infraduction of this eye was felt. He had already been operated on in another clinic, but the surgeon could not succeed in hooking his superior rectus. With great difficulty, the only thing that we could do was a free tenotomy of the superior rectus. As the eye was equilibrated in a moderate abduction, we performed an $8 \mathrm{~mm}$ recession of the lateral rectus. As there was still a small hypertropia and exotropia postoperatively, we performed in a second operation an eight millimeters resection of the medial rectus, a recession with anterior transposition of the inferior oblique and an advancement of the inferior rectus according to the Romero-Apis technique, in order to avert circulatory problems to the anterior segment of the eye. As he presented a small blepharoptosis, we did, in a third surgery, a tarsectomy according to the Fasanella-Servat technique, with good result. He ended with good eye position, almost no limitation of the horizontal movements and -3 limitation of up and down ductions. The magnetic resonance imaging showed an altered image of the superior rectus, suggesting fibrosis post myositis.
\end{abstract}

Keywords: Oculomotor muscles/surgery; Strabismus/etiology; Blepharoptosis/surgery; Fibrosis/etiology; Ophthalmologic surgical procedures; Case report; Human Male; Child

\section{RESUMO}

Os autores relatam o caso de um menino de 5 anos que, até os 2 anos, possuía ol hos normais, quando seu olho direito começou a desviar para cima e lateralmente, até chegar a esconder-se sob a pálpebra superior. À cirurgia, notou-seforte limitaçäo passiva de abaixamento desse ol ho. Elejá havia sido operado em outra clínica, mas o colega não conseguiu enganchar o reto superior. Numa segunda operação, o único que conseguimos foi uma tenotomia livre do reto superior; como o olho ficou equilibrado em abdução, fizemos um retrocesso de $8 \mathrm{~mm}$ do reto lateral. Como restou moderada exotropia e pequena hipertropia, numa terceira operação fizemos uma resseç̧ão de $8 \mathrm{~mm}$ do reto medial, um retrocesso com transposição anterior do oblíquo inferior e um avançamento do reto inferior segundo a técnica de Romero-Apis, para evitar transtornos circulatórios ao segmento anterior do olho. Como restou pequena blefaroptose, realizamos, numa quarta operação uma tarsectomia segundo Fasanella-Servat. O paciente terminou com o olho direito bem posicionado, sem limitações aos movimentos horizontais e limitação de -3 dos verticais. A imagem de ressonância magnética demonstrou alterações do reto superior, sugerindo fibrose após miosite.

Descritores:Músculos oculomotores/cirurgia; Estrabismo/etiologia; Blefaroptose/cirurgia; Fibrose/etiologia; Procedimentos cirúrgicos oftalmológicos; Relato de caso; Humanos; Masculino; Criança

\section{INTRODUCTION}

Several types of congenital fibrosis of oculomotor muscles, frequently associated with other systemic anomalies, have been well documented ${ }^{(1)}$, since the publication of Baumgarten, in $1840^{(2)}$.

Three years ago we published, with A. Scott and A.H. Wang, three cases of acquired fibrosis of oculomotor muscles ${ }^{(3)}$, which developed over a period of few months in otherwise normal children, ending as large angle restrictive deviations of difficult surgical correction. Our case 2 presented an acquired isolated progressive right superior rectus fibrosis, ending with a huge hypertropia; the cases 1 and 3 had acquired right eye isolated medial rectus fibrosis with large esotropia. Based on some suggestive findings, we hypothesized that inflammation could be the cause of the phenomenon.

We report here an additional case of acquired progressive fibrosis of extraocular muscles in infant.

\section{CASE REPORT}

A 4 years old boy who had normal gestation and birth. There is no family history of strabismus. Normal eye alignment and eye movements were present up to 2 years of age, when his right eye started to deviate upward and laterally. At 5 years of age, when we saw him by first time, he presented a huge right hypertropia and exotropia (the right eye was hidden under the superior eyelid (Figure 1). The eye could not infraduct actively. The nuclear magnetic resonance imaging (MRI) showed that the right superior rectus presented hypotrophy, irregular contour and shortening. The muscle presents low signal in $\mathrm{T} 1$ and $\mathrm{T} 2$, with predominantly peripherical impregnation by gadolinium. According to the radiologist, these dates suggest postinflammatory muscle fibrosis. A colleague from other state of the country tried to operate him before but he did not succeed in hooking the superior rectus; he sutured the conjunctiva and directed him to the Extraocular Muscle Motility Section of the Ophthalmology Department of the Santa Casa de São Paulo. We operated on him a few months later. The right eye could not be passively infraducted. A blind superior rectus tenotomy was accomplished as well as scar adherences excision, which released the passive restriction to infraduction. As a small adduction restriction was also found, an $8 \mathrm{~mm}$ lateral rectus recession was done; this muscle was thin and had a little reduced elasticity. As small exotropia and hypertropia were still observed postoperatively, we reoperated on him 20 days after the first surgery. The passive

Submitted for publication: April 8, 2009

Accepted for publication: November 15, 2010

Study carried out at the Faculdade de Ciências Médicas da Santa Casa de Misericórdia de São Paulo.

Physician, Ophthalmology Department, Faculdade de Ciências Médicas da Santa Casa de Misericórdia de São Paulo, São Paulo (SP), Brazil.

Professor, Ophthalmology Department, Faculdade de Ciências Médicas da Santa Casa de Misericór-

dia de São Paulo, São Paulo (SP), Brazil.

Funding: No specific financial support was available for this study.

Disclosure of potential conflicts of interest: C.R.Souza-Dias, None; M.Goldchmit, None; C.F.Uesugui, None.

Correspondence address: Carlos Ramos de Souza-Dias. Rua Cincinato Braga, 59, Cj. 5B2 - São Paulo - SP - 01333-011 - Brazil - E-mail: csdias@uol.com.br 

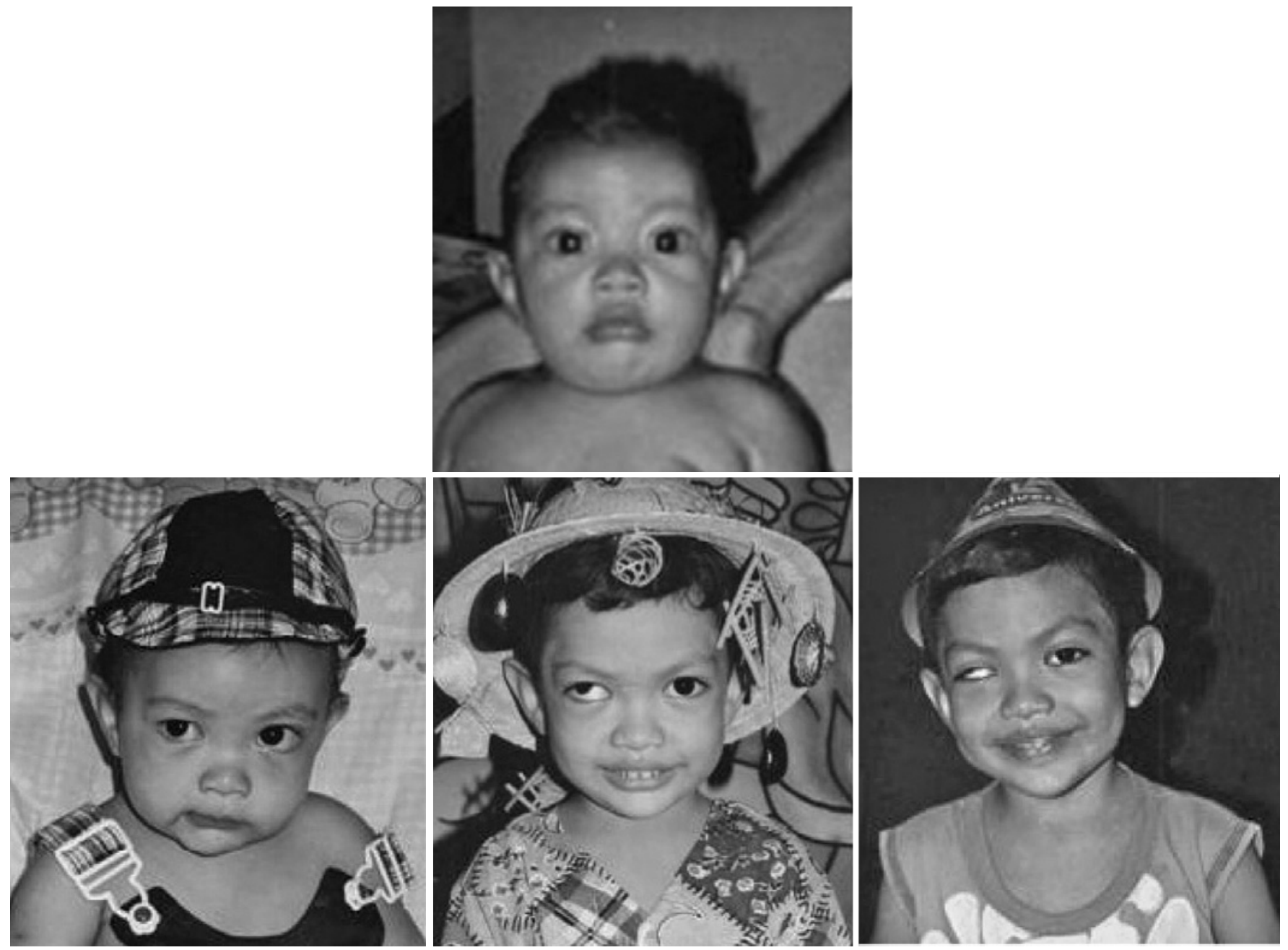

Figure 1. Above - The boy at 8 months of age. Well aligned eyes; Below - Left: At 2 years of age, his right eye started to elevate; Center: At 3 years of age, a large right hypertropia; Right: His appearance when he came to our service, after an inefficacious attempt of surgical correction by a colleague. His right eye was hidden under the upper lid.

infraduction showed only a small restriction, felt at the end of the movement, and the passive adduction was normal; we performed a $7 \mathrm{~mm}$ right medial rectus resection, a right inferior oblique recession with anterior transposition with $5 \mathrm{~mm}$ resection, and an $8 \mathrm{~mm}$ inferior rectus $U$ tucking, according to the Romero-Apis technique ${ }^{(4)}$, in order to preserve the ciliary arteries. One month after this surgery, he had good alignment in primary position, good horizontal movements and a -3 restriction of both vertical movements (Figure 2 A). His visual acuity was lesser than 20/200 in the right eye and 20/20 in the left eye with correction of a small hypermetropia. As there was a small blepharoptosis, 3 months after the second operation we performed a superior tarsectomy according to Fasanella-Servat; the last time that we could see him, the ptosis was better, although there was still some edema.

\section{DISCUSSION}

In 1969, some authors ${ }^{(5)}$ reported a case of unilateral probably acquired fibrosis of the inferior rectus, represented by a large angle hypotropia which was noted by his mother at two months of age. At surgery, the inferior rectus was seen as a thin and taut fibrous band. The authors said that "It is not known if the deviation was present at birth". No other published case of confirmed acquired progressive extraocular muscle fibrosis in infant could be found, except our own three cases aforementioned ${ }^{(3)}$.
The pathogenesis of those cases of acquired oculomotor muscles fibrosis in infant is not clear. In the case 2 of the 3 cases published by $u^{(3)}$, we did serologic tests for Graves' disease, which were normal. Chan et al. ${ }^{(6)}$, out of 83 children with Graves' disease, only one showed restricted motility which was of mild degree, making this an unlikely etiology of our present case.

In the case 1 of our previous reported 3 cases $^{(3)}$, the MRI showed fuzziness around the medial and inferior rectus muscles, which was interpreted by the radiologist as typical of myositis. In the case 2 of that presentation, the computerized tomography (CT) showed an enlarged superior rectus and the CT and MRI of case 3 showed also enlarged medial and inferior rectus muscles. In our present case, the MRI showed that the right superior rectus presented hypotrophy, irregular contour and shortening. The muscle presents low signal in $\mathrm{T} 1$ and $\mathrm{T} 2$, with predominantly peripherical impregnation by gadolinium. According to the radiologist, these data suggest postinflammatory muscle fibrosis.

Based on their acquired characteristic and the CT and MRI aspects of the aforementioned cases, we hypothesized that a subacute myositis could be the pathogenetic factor of those muscles fibrosis and shortening. In the case 1 of our 3 previously reported cases $^{(3)}$, there was no alignment change after a trial of systemic prednisone at 4 months of age, when the deviation was definitively established. Perhaps if the diagnosis was made at the beginning of the deviation, the steroid treatment could be effective in interrupting its progress. 


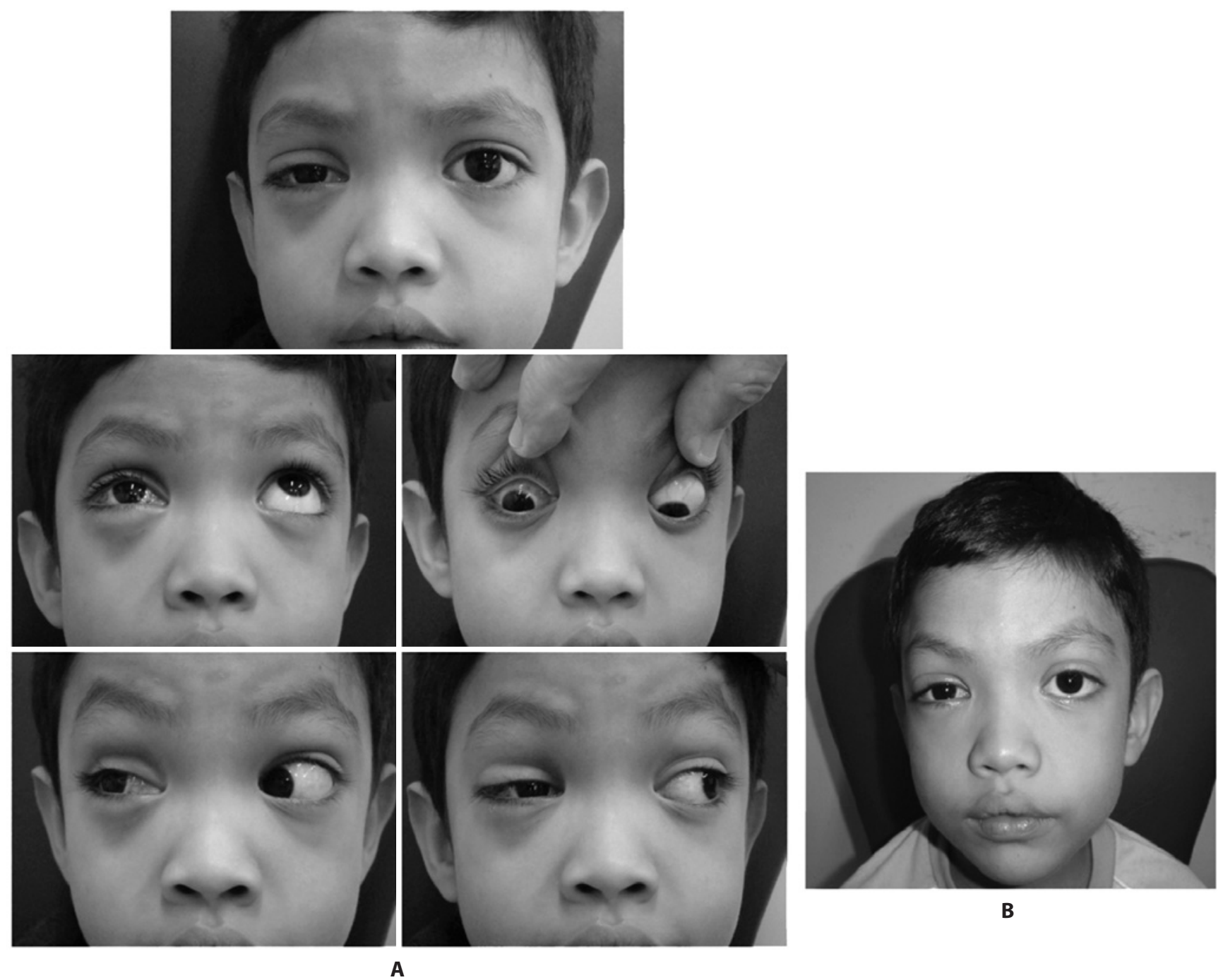

Figure 2. A) One month after the second operation. Good alignment of the eyes in primary position, limitation of elevation and depression (-3) and good lateroversions; a small blepharoptosis. B) Fifteen days after a right tarsectomy with the Fasanella-Servat technique. There was still a mild edema, but it was the last time that we could see him.

In addition, it seems valid to hypothesize that the congenital cases of isolated muscle fibrosis, as generally happen with the superior and inferior rectus muscles, could have as their pathogenesis an intrauterine myositis. Imaging studies of cases of congenital fibrosis of the extraocular muscles may demonstrate atrophy or thickening of the extraocular muscles ${ }^{(7,8)}$, like we observed in our 4 cases.

It is interesting the fact that a free tenotomy of the superior rectus in the case 2 of our previous report ${ }^{(3)}$ and in the present case did not cause hypotropia. The first one ended with orthotropia in primary position, normal infraduction and a slight limitation of supraduction. In the present case, the free tenotomy of the superior rectus was not sufficient for correcting the hypertropia, requiring a shortening of the inferior rectus and recession with anterior transposition, with $5 \mathrm{~mm}$ resection, of the inferior oblique in order to achieve a good vertical alignment in primary position, leaving a -3 limitation of elevation and depression; this kind of surgery was already reported by other authors ${ }^{(1,9)}$, both for treatment of congenital fibrosis of the extraocular muscles. Probably the small limitation of elevation observed after our first operation was caused by scar adherences caused by two difficult operations. Our experience with congenital fibrosis of superior and inferior recti is that the free teno- tomy of these muscles also does not produce overcorrection of the deviation ${ }^{(10)}$.

\section{REFERENCES}

1. Crawford JS. Congenital fibrosis syndrome. Can J Ophthalmol. 1970:5(4):331-6.

2. Baumgarten M apud Jaafar M, Traboulsi El. Congenital fibrosis of the extraocular muscles. In: Rosenbaum AL, Santiago AP editors. Clinical strabismus management. Philadelphia: WB Saunders; 1999. p.363.

3. Souza-Dias C, Scott AB, Wang AH. Progressive restrictive strabismus acquired in infancy. Br J Ophthalmol. 2005;89(8):986-7.

4. Romero-Apis D. Estrabismo. México: Editorial Auroch; 2000. p.382.

5. Paolillo RD, Burch OG, Torchia RT. Infantile contracture of inferior rectus muscle with resultant mechanical hypotropia. Am J Ophthalmol. 1969;68(6):1057-60.

6. Chan W, Wong GW, Fan DS, Cheng AC, Lam DS, Nq JS. Ophthalmopathy in childhood Graves' disease. Br J Ophthalmol. 2002;86(7):740-2.

7. Hupp SL, Williams JP, Curran JE. Computerized tomography in the diagnosis of the congenital fibrosis syndrome. J Clin Neurophthalmol. 1990;10(2):135-9.

8. Wilder WM, Williams JP, Hupp SL. Computerized tomography findings in two cases of congenital fibrosis syndrome. Comput Med Imaging Graph. 1991;15(5):361-3.

9. Apt L, Axelrod RN. Generalized fibrosis of the extraocular muscles. Am J Ophthalmol. 1978;85(6):822-9.

10. Prieto-Díaz J, Souza-Dias C. Strabismus, $5^{\underline{a}}$ ed. Buenos Aires, Ediciones Científicas Argentinas; 2005. 